\title{
Comparison of a Time Series Analysis of Bulk Tank Somatic Cell Counts of Dairy Herds Located in Brazil and the United States
}

\author{
Liz Gonçalves Rodrigues ${ }^{1,3}$, Maria Helena Cosendey de Aquino ${ }^{2,3}$, Márcio Roberto Silva ${ }^{4}$, \\ Letícia Caldas Mendonça ${ }^{4}$, Juliana França Monteiro de Mendonça ${ }^{5}$, Guilherme Nunes de \\ Souza ${ }^{2,4 *}$ \\ ${ }^{1}$ Federal Agriculture Superintendence in the State of Alagoas, Maceio, Brazil \\ ${ }^{2}$ Department of Public Health and Veterinary Public Health, Faculty of Veterinary Medicine, Federal \\ Fluminense University, Niterói, Brazil \\ ${ }^{3}$ Pos-Graduation in Veterinary Hygiene and Technology Processing of Animal Products, Faculty of Veterinary \\ Medicine, Federal Fluminense University, Niterói, Brazil \\ ${ }^{4}$ Embrapa Dairy Cattle, Juiz de Fora, Brazil \\ ${ }^{5}$ Research Support Foundation of Minas Gerais State, Brazil
}

*Corresponding Author: Guilherme Nunes de Souza, Department of Public Health and Veterinary Public Health, Faculty of Veterinary Medicine, Federal Fluminense University, Niterói, Brazil. Email: guilherme.souza@embrapa.br

\begin{abstract}
Bulk tank somatic cell counts (BTSCC) is widely used to monitoring the mammary gland health at the herd and regional level. A time series of BTSCC from specific regions or countries can be used to compare the mammary gland health according to regions and estimate the trend of subclinical mastitis of dairy herds at the regional level. This data support economic decisions related to mastitis control at the regional herd level. Still, decisions at the regional or country level are mainly used to investigate the efficiency of the mastitis control program. Three time series of BTSCC from dairy herds located in the USA and the southeastern region of Brazil were evaluated from 1995 to 2014. The first and second USA time series presented an increasing and decreasing trend for the annual geometric mean of BTSCC and the percentage of dairy herds with BTSCC greater than 400,000 cells $/ \mathrm{mL}$, respectively. The Brazil time series showed no decreasing trend for the annual geometric mean of BTSCC or for the percentage of dairy herds with a BTSCC greater than 400,000 cell $\mathrm{s} / \mathrm{mL}$; consequently, approximately 40 to $50 \%$ of the dairy herds from southeastern Brazil will not achieve the regulatory limits for BTSCC of 400,000 cells $/ m$ Lover the next several years.
\end{abstract}

Keywords: Bulk Tank Somatic Cell Counts; Time Series; Bovine Mastitis; Brazil; United States

\section{INTRODUCTION}

Mastitis is an endemic disease in dairy herds worldwide and causes, among other problems, the greatest economic loss related to production diseases [1,2]. Decisions related to the control of mastitis can occur at the cow, farm, regional or country level [2]. For instance, decisions at the regional or country level are those that are mainly related to data collection and include data collection(database) from a given region and its population to investigate the benefits of mastitis control programs[3, 4, 5]. Somatic cell counts (SCC) are widely recognized as a subclinical mastitis indicator and are used in the evaluation and monitoring of the health of the mammary gland in dairy herds in several countries [6]. In an effort to improve product quality and, indirectly, farm productivity, regulatory limits on SCC have been established by many of the major dairy producing countries. In Europe, the Council Directive 92/46 of the Council of the European Communities in April 1992 stated that milk with SCC over 400,000 cells/mL may not be used for fluid milk and, starting in 1998, not even for human consumption. In North America, limits are placed at 750,000 cells/mL (USA) and 500,000 cells/mL (Canada) [7]. In July of 2016, a limit of 400,000 cells $/ \mathrm{mL}$ will be established for dairy herds located in the southeastern of Brazil.[8].

Monitoring SCC at the herd and regional level requires longitudinal data [6]. A time series 
analysis of BTSCC of dairy herds from a specific region or country can provide information about a situation and trend of subclinical mastitis at the regional or country level and is useful to make decisions on the mastitis control program. Countries which establish a regulatory limit for BTSCC can use a time series to asses trends of herds that do not achieve these limit. For instance, the time series of BTSCC from 1994 to 2004 in Irish dairy herd showed different trends according to specific periods [9]. In Canada, the time series from 1985 to 1991 showed substantial decrease of BTSCC due to regulatory limit [10].

Comparing the time series of BTSCC of dairy herds from different regions or countries can be useful to identify similarities and/or differences related to the health of the mammary gland and help make decisions at the regional or country level for the mastitis control program. The objective of the present study was to evaluate the differences between a time series of BTSCC from dairy herds located in the southeastern region of Brazil and the United States from 1995 until 2014.

\section{MATERIAL AND METHODS}

\subsection{Herds and Data from Brazil and the United States}

Data regarding BTSCC from 2006 to 2014 of dairy herds located in the southeastern region of Brazil were obtained from the Milk Quality Laboratory of Embrapa Dairy Cattle (Juiz de Fora, Brazil). Data regarding BTSCC from 1995 to 2013 of dairy herds located in the United States were obtained from the Council on Dairy Cattle Breeding Research Report[11]. The time series of BTSCC from the United States dairy herds used in this study was related to the annual geometric mean of BTSCC and the percentage of dairy herds with an annual geometric mean greater than 400,000 cells $/ \mathrm{mL}$. The number of herds of each country and year, the annual geometric mean of BTSCC (AGM)and percentage of dairy herds with a geometric mean of SCC greater than 400,000 cells $/ \mathrm{mL}$ ('\%>400') are presented in Table 1.

Table1. Number of dairy herds, annual geometric mean of bulk tank somatic cell counts (x 1,000 cells $/ \mathrm{mL})$ and percentage of dairy herds with bulk tank somatic cell counts greater than 400,000 cells/mL according to the country and year

\begin{tabular}{|c|c|c|c|c|c|c|}
\hline \multirow[t]{2}{*}{ Year } & \multicolumn{3}{|c|}{ United States $^{\mathrm{a}}$} & \multicolumn{3}{|c|}{ Brazil } \\
\hline & $\mathrm{N}^{\mathrm{b}}$ & $\mathrm{AGM}^{\mathrm{c}}$ & $\%>400^{\mathrm{d}}$ & $\mathrm{N}$ & AGM & $\%>400$ \\
\hline 1995 & 265,844 & 304 & 27.2 & - & - & - \\
\hline 1996 & 255,039 & 308 & 27.8 & - & - & - \\
\hline 1997 & 287,789 & 314 & 28.8 & - & - & - \\
\hline 1998 & 283,695 & 318 & 30.3 & - & - & - \\
\hline 1999 & 273,364 & 311 & 29.8 & - & - & - \\
\hline 2000 & 260,139 & 316 & 29.5 & - & - & - \\
\hline 2001 & 244,940 & 322 & 31.1 & - & - & - \\
\hline 2002 & 267,809 & 320 & 30.0 & - & - & - \\
\hline 2003 & 251,182 & 319 & 30.4 & - & - & - \\
\hline 2004 & 240,938 & 295 & 26.4 & - & - & - \\
\hline 2005 & 234,585 & 296 & 25.8 & - & - & - \\
\hline 2006 & 236,191 & 288 & 25.2 & 12,895 & 512 & 53.4 \\
\hline 2007 & 227,626 & 276 & 24.0 & 15,285 & 521 & 57.6 \\
\hline 2008 & 222,245 & 262 & 22.4 & 15,976 & 468 & 49.6 \\
\hline 2009 & 204,195 & 233 & 18.9 & 15,771 & 564 & 59.8 \\
\hline 2010 & 198,218 & 228 & 18.0 & 16,019 & 473 & 48.0 \\
\hline 2011 & 191,375 & 217 & 15.7 & 15,715 & 571 & 61.7 \\
\hline 2012 & 184,927 & 200 & 12.0 & 16,390 & 528 & 55.1 \\
\hline 2013 & 177,944 & 199 & 11.6 & 14,510 & 498 & 51.3 \\
\hline 2014 & - & - & - & 14,104 & 536 & 55.5 \\
\hline
\end{tabular}

a Source: Norman and Walton (2014)

${ }^{b}$ Number of dairy herds

${ }^{c}$ Annual geometric mean

${ }^{d}$ Percentage of dairy herds with bulk tank somatic cell counts greater than 400,000 cells $/ \mathrm{mL}$ 


\subsection{Statistical Analyses}

Data from the United States dairy herds [11] were divided into two time series. The first and second time series were from 1995 to 2003 and from 2004to 2014, respectively. Descriptive statistics were performed using the number of dairy herds, AGM and $\%>400$ ' according to the countries and the time series. The normality of the data of the number of dairy herds, AGM and '\%> 400' for each time series distribution was evaluated by the Shapiro-Wilk test. The significance of the arithmetic mean differences between the number of dairy herds, AGM and '\%> 400' according to time series was determined by an independent samples $t$-test. Levene's test was used to evaluate the variance between the time series. Linear regression analyses were conducted using the AGM and ' $\%>400$ ' as the dependent variables (y) and the year as the independent variable (x). Thus, three linear regression analyses were performed to compare the slope among the time series according to the dependent variables. The linear regression and angular coefficients were evaluated for statistical significance. The statistical analyses were performed using SPSS version 8.0 [12].

\section{RESULTS AND DISCUSSION}

The three time series evaluated in this study presented a normal distribution for the number of herds according to the results of the ShapiroWilk test $(p>0.05)$. Levene's test showed equal variance for both of the USA time series when compared with the Brazil time series for ' $\%>400$ ' but different variances between the USA and the Brazil time series for AGM.

The independent samples $t$-test showed that the means of the number of dairy herds according to the countries and time series were different $(\mathrm{p}$ $<0.05$ ) (Table 2). Therefore, the size of the population of the dairy herds should be regarded when comparing the time series of AGM and ' $\%>400$ '.

Table2. Descriptive statistics of the number of dairy herds according to the countries and the time series

\begin{tabular}{|l|c|c|c|c|c|c|c|}
\hline \multicolumn{1}{|c|}{ Country/Time series } & $\mathrm{N}^{\mathrm{b}}$ & Mean* & $\mathrm{SD}^{\mathrm{c}}$ & \multicolumn{2}{|c|}{$\mathrm{IC}^{\mathrm{I}} 9 \%^{\mathrm{d}}$} & \multirow{2}{*}{ Min } & Max \\
\cline { 5 - 6 } & & & & $\mathrm{LB}^{\mathrm{e}}$ & $\mathrm{UB}^{\mathrm{f}}$ & & \\
\hline USA/1995-2003 & 9 & $265,533^{\mathrm{A}}$ & 14,409 & 254,457 & 276,609 & 244,940 & 287,789 \\
\hline USA/2004-2013 & 10 & $211,824^{\mathrm{a}}$ & 23,215 & 195,217 & 228,431 & 177,944 & 240,938 \\
\hline Brazil/2006-2014 & 9 & $15,185^{\mathrm{C}}$ & 1,133 & 14,314 & 16,056 & 12,895 & 16,390 \\
\hline
\end{tabular}

* Different capital letter between rows means statistical difference $(p<0.05)$.

a Source: Norman and Walton (2014)

${ }^{b}$ Number of year in time series

${ }^{c}$ Standard deviation

${ }^{d} 95 \%$ confidence interval for the mean

${ }^{e}$ Lower bound

${ }^{f}$ Upper bound

Min-Minimum

Max - Maximum

The three time series evaluated in this study presented a normal distribution for AGM and '\%>400' according to the results of the ShapiroWilk test $(\mathrm{p}>0.05)$. Levene's test showed equal variance for the USA time series from 2004to 2013 and the Brazil time series. Different variances were observed when compared to the USA time series from 1995 to 2003 and the Brazil time series for both variables. In this situation, the significance of the difference between the means of the USA time series when compared with mean of the Brazil time series did not show equal variances.

ARC Journal of Animal and Veterinary Sciences
The annual geometric mean of BTSCC according to the countries and the time series were different, as shown by an independent samples $t$-test $(\mathrm{p}<0.05)$ (Table 3$)$. The results showed a significant reduction of AGM from the USA dairy herds from the first to the second time series. The means of ' $\%>400$ ' according to the countries and time series were also different, as shown by the independent samples $t$-test ( $\mathrm{p}$ $<0.05$ ) (Table 3). This result suggests that the situation regarding subclinical mastitis is different between both USA time series and between the Brazil and USA time series. An improvement of the mammary gland health in 
the USA during the entire time period was observed with a mean reduction of approximately $20 \%$ of AGM and $10 \%$ of dairy herds with a geometric mean of BTSCC greater than 400,000 cells $/ \mathrm{mL}$ from the first to second time series. In all of the period related to the first USA time series, an increase of 15,000 cells/mL for AGM and approximately of $3 \%$ for

Table3. Descriptive statistics of the annual geometric mean of the bulk tank somatic cell counts $(A G M)(\times 1,000$ cells $/ \mathrm{mL}$ ) and the percentage of dairy herds with bulk tank somatic cell counts greater than 400,000 cells $/ \mathrm{mL}$ (\%>400) according to the countries and time series

\begin{tabular}{|c|c|c|c|c|c|c|}
\hline \multirow[t]{2}{*}{ Variable } & \multirow[t]{2}{*}{ Country/Time series } & \multirow[t]{2}{*}{$\mathrm{N}^{\mathrm{b}}$} & \multirow[t]{2}{*}{ Mean* } & \multirow[t]{2}{*}{$\mathrm{SD}^{\mathrm{c}}$} & \multicolumn{2}{|c|}{ IC $95 \%^{\mathrm{d}}$} \\
\hline & & & & & LB & UB \\
\hline \multirow{3}{*}{ AGM } & USA/1995-2003 a & 9 & $314^{\mathrm{B}}$ & 6 & 310 & 319 \\
\hline & USA/2004-2013 ${ }^{\mathrm{a}}$ & 10 & $249^{A}$ & 38 & 221 & 276 \\
\hline & Brazil/2006-2014 & 9 & $518^{\mathrm{C}}$ & 35 & 491 & 546 \\
\hline \multirow{3}{*}{$\%>400$} & USA/1995-2003a & 9 & $29.4^{\mathrm{B}}$ & 1.3 & 28.4 & 30.4 \\
\hline & $\mathrm{USA} / 2004-2013^{\mathrm{a}}$ & 10 & $20.0^{A}$ & 5.6 & 15.9 & 24.0 \\
\hline & Brazil/2006-2014 & 9 & $54.7^{\mathrm{C}}$ & 4.6 & 51.1 & 58.2 \\
\hline
\end{tabular}

*Different capital letters between rows means statistical differences $(p<0.05)$

${ }^{a}$ Source: Norman and Walton (2014)

${ }^{b}$ Number of years in the time series

${ }^{c}$ Standard deviation

${ }^{d} 95 \%$ confidence interval for the mean

$L B$ - Lower bound

$U B$ - Upper bound

The linear regression models of AGM were statistically significant $(p<0.01)$ for the first and second USA time series. Similarly, the linear regression models for $\%>400$ ' were also statistically significant $(\mathrm{p}<0.01)$ for the first and second USA time series (Table 4). The first and second USA time series presented an increasing and decreasing trend of AGM, respectively. The same increasing and decreasing trends were observed for ' $\%>400$ ' for USA dairy herds according to the time series. The linear regression model for the first USA time series estimated an increase of approximately 2,000
' $\%>400$ ' was observed. In contrast, the second USA time series showed a decrease of 96,000 cells $/ \mathrm{mL}$ and approximately $15 \%$ for AGM and '\%>400', respectively. However, a decrease of $4 \%$ was observed from the last year of the first USA time series (2003) to the first year of the second USA time series (2004).

Table4. Linear regression analysis for the annual geometric mean of the bulk tank somatic cell counts (AGM) and the percentage of dairy herds with bulk tank somatic cell counts greater than 400,000 cells/mL (\%>400) according to countries and years

\begin{tabular}{|l|l|l|c|c|}
\hline Dependent variable & Country/Time series & Linear regression & $\mathrm{P}$ & $\mathrm{R}^{2}$ \\
\hline \multirow{3}{*}{ AGM } & $\mathrm{USA} / 1995-2003^{\mathrm{a}}$ & $\mathrm{y}=305.5+1.83 \mathrm{x}$ & $<0.01$ & 0.705 \\
\cline { 2 - 5 } & $\mathrm{USA} / 2004-2013^{\mathrm{a}}$ & $\mathrm{y}=318.2-12.511 \mathrm{x}$ & $<0.001$ & 0.966 \\
\cline { 2 - 5 } & $\mathrm{Brazi} / 2006-2013$ & $\mathrm{y}=506.1+2.56 \mathrm{x}$ & 0.609 & 0.039 \\
\hline \multirow{3}{*}{$\%>400$} & $\mathrm{USA} / 1995-2003^{\mathrm{a}}$ & $\mathrm{y}=27.5+0.39 \mathrm{x}$ & $<0.01$ & 0.691 \\
\cline { 2 - 6 } & $\mathrm{USA} / 2004-2013^{\mathrm{a}}$ & $\mathrm{y}=29.9-1.81 \mathrm{x}$ & $<0.001$ & 0.960 \\
\cline { 2 - 6 } & $\mathrm{Brazil} / 2006-2013$ & $\mathrm{y}=54.4+0.04 \mathrm{x}$ & 0.951 & 0.001 \\
\hline
\end{tabular}

${ }^{a}$ Source: Norman and Walton (2014)

$P$ - Model significance level

$R^{2}$ - Determination coefficient (model adjustment) 
In the Brazil time series, the AGM and '\%>400'means were 518,000 cells $/ \mathrm{mL}$ and $54.7 \%$, respectively. The Brazil AGM was 1.65 and 2.10 times greater than the first and second USA time series, respectively. The mean of the'\%>400' in the dairy herds located in the southeastern region of Brazil was 25.3 and $34.7 \%$ greater than the first and second USA time series, respectively (Table 4). The linear regression model for the Brazil time series was not statistically significant for either of the dependent variables $(\mathrm{p}>0.05)$.

The location and number of dairy herds used in the USA time series provide adequate information to make an inference for the USA dairy herds because the data obtained were representative of the entire country. The results showed a significant reduction of USA dairy herds from the first to second time series. Although the dairy herds from Brazil were not randomly selected, the location and number of dairy herds used in the Brazil time series provide adequate information to make an inference for the dairy herds located in the southeastern region of Brazil, which is an important region for milk production in Brazil. The data of the Brazil time series of BTSCC were from dairy herds located in the southeastern region. Therefore, the results and inference regarding BTSCC can be applied only to dairy herds located in this region of Brazil.

Although the first USA time series from 1995 to 2003 showed a reduction in the number of herds over time (almost 15,000 dairy herds), there was a slight increase in the AGM and ' $\%>400$ '. In this period, at the country level, no improvement was observed in the subclinical mastitis situation. This situation suggests that the control and prevention procedures of subclinical mastitis were not homogeneously and not efficiently adopted in the country, which could be observed in the BTSCC time series. In contrast, the second USA time series showed a decrease in the number of dairy herds, AGM and ' $\%>400$ '. In this time series, a significant improvement in the subclinical mastitis situation was observed from 2004 to 2013.

In 2007, the National Animal Health Monitoring System (NAHMS) performed a national study to estimate the prevalence of mastitis contagious pathogens [13]. Of the three contagious mastitis pathogens, $S$. aureus had the highest herd-level prevalence at $43.0 \%$ of the dairy herds, whereas $S$. agalactiae and Mycoplasma spp. were found in 2.6 and $3.2 \%$ of dairy herds, respectively. In the same year, 2007, the AGM was 276,000 cells $/ \mathrm{mL}$, and $24 \%$ of the USA dairy herds presented an annual geometric mean of BTSCC greater than 400,000 cells $/ \mathrm{mL}$. Therefore, the AGM and ' $\%>400$ ' for USA dairy herds for 2007 were associated with prevalence of 43.0, 2.6 and $3.2 \%$ for $S$. aureus, S. agalactiae and Mycoplasma spp., respectively. The second USA time series presented a decrease of approximately $15 \%$ for dairy herds that presented a BTSCC greater than 400,000 cells $/ \mathrm{mL}$ (Table 2), suggesting that the prevalence of subclinical mastitis, and consequently the prevalence between herds for contagious mastitis pathogens, also decreased. Dividing the data of the USA dairy herds into two time series allowed the identification of acritical period where there was an increase of AGM and $\%$ > 400'. After this period, a decrease of both variables was observed, indicating an improvement of mammary gland health.

Since the introduction of a standard mastitis prevention program [14], there has been much progress in decreasing the prevalence of subclinical mastitis, which is mainly caused by Staphylococcus aureus and Streptococcus agalactiae agalactiae, and consequently a decrease in the BTSCC in national milk production has been achieved [6]. The main approach for the control and prevention of $S$. agalactiae should be directed toward eradication of this pathogen through treatment of infected cows. In contrast, the approach for the control measure of $S$. aureus should be based on the culling of cows with chronic infection due to its difficult elimination [15]. The decrease of approximately 63,000 USA dairy herds and the consequent elimination of chronically infected dairy cows from these herds can be one of the causes responsible for the decrease of AGM and $' \%>400$ '. However, this association with the elimination of chronically infected dairy cows suggests that the main control measures improvement at the country level [2]. The percentage of USA dairy herds that exceeded the legal limit would also have been higher than the percentage of herds that had milk rejected from the market because market exclusion only occurs after repeated violations [11].

The Brazil time series of AGM and ' $\%>400$ ' showed that the control of subclinical mastitis is one of the challenges of the Brazilian dairy industry located at southeastern region. This critical situation is mainly due to a high 
percentage of dairy herds with a BTSCC greater than 400,000 cells $/ \mathrm{mL}$, which is the regulatory limit established by Brazilian legislation for these dairy herds after July of 2016 [8]. When comparing the BTSCC parameters from the Brazil dairy herds with both of the USA time series, the results suggest that the prevalence between dairy herds for $S$. aureus and $S$. agalactiae were greater than 43.0 and $2.6 \%$, respectively. A high ' $\%>400$ ' was observed (Table 3), which suggests that the specific procedures according to contagious mastitis pathogens are not widespread and were not adopted efficiently in dairy herds in the southeastern region of Brazil.

According to the linear regression models, the situation related to AGM and ' $\%>400$ ' in dairy herds located at the southeastern region of Brazil will not increase or decrease suddenly. Regarding the confidence interval of $95 \%$ for the mean, the AGM and ' $\%>400$ ' will range from 491,000 and 546,000 cells $/ \mathrm{mL}$ and from 51.1 to $58.2 \%$, respectively, for the next couple of years if mastitis control procedures at the herd and regional level are not adopted, which is mainly related to contagious pathogens. Even if milking procedures to control mastitis was adopted at the regional level but if there is not a heavy culling of the cows with chronic infection, the AGM and ' $\%>400$ ' will not decrease suddenly. Considering the second USA time series of BTSCC, a decrease of $20 \%$ of the herds with a BTSCC greater than 400,000 cells $/ \mathrm{mL}$ is possible within 10 years. In southeastern Brazil, if the design and adoption of a mastitis control program at the herd and regional level occurs in a short time, the decrease of BTSCC will occur over a medium or long time. Therefore, in regards to the regulatory limits established in Brazil, a trend of maintaining the percentage found in this study for dairy herds with a BTSCC greater than 400,000 cells $/ \mathrm{mL}$ will keep for the next several years.

Subclinical mastitis in dairy herds from the USA and the southeastern region of Brazil presented differences according to a time series. Dairy herds from the southeastern region of Brazil did not present a trend of improvement related to a decrease of BTSCC, and approximately 50\% of the dairy herds will not achieve the regulatory limits. Monitoring BTSCC at the regional or country level over time provides an opportunity to evaluate progress in the dairy industry and study relationships between the parameters of dairy herds and estimate the efficacy of mastitis control programs.

\section{ACKOWLEDGEMENTS}

Conselho Nacional de Pesquisa (Edital MCT CNPq 014/2010 - Processo 477493/2010-6) and Fundação de Amparo à Pesquisa do Estado de Minas Gerais (FAPEMIG - APQ CVZ 01305/2010) for financial support.

\section{REFERENCES}

[1] Bennet, R. M., Christiansen, K., CliftonHadley, R.S., Estimating the costs associated with endemic diseases of dairy cattle,JDairy Res., 66, pp. 455-459(1999).

[2] Halasa, T., Huijps, K., Osteras, O., Hogeveen, $\mathrm{H}$., Economic effects of bovine mastitis management: a review, Vet Q, 29, pp. 18-31 (2007).

[3] Beek, H.S., Wise, W.S., Dodd, F.H., Costs benefit analysis of bovine mastitis in the UK, $\mathrm{J}$ Dairy Res., 59, pp. 449-460, (1992).

[4] Keefe, G. P., Streptococcus agalactiae mastitis: a review, Can Vet J, 38, pp. 429-435 (1997).

[5] Hall, D.C., Ehui, S.K., Sahpiro, B.I., Economic analysis of the impact of adopting herd health control programs on smallholder dairy farms in Central Thailand, Agricultural Economics, 31, pp. 335-342 (2004).

[6] Schukken, Y. H., Wilson, D. J., Welcome, F., Garrison-Tikofsky, L., Gonzalez, R. N., Monitoring udder health and milk quality using somatic cell counts, Vet Res., 34, pp. 579-596 (2003).

[7] Sargeant J.M., Schukken Y.H., Leslie K.E., Ontario bulk milk somatic cell count reduction program: progress and outlook, J Dairy Sci., 81, pp. 1545-1554 (1998).

[8] Brazil. 2011. Instrução Normativa $n^{\circ} 62$ de 29 de Dezembro de 2011. Regulamento Técnico de Identidade e Qualidade de Leite Cru Refrigerado. Diário Oficial da União, 29 de Dezembro de 2011. Ministério da Agricultura, Pecuária e Abastecimento.

[9] Berry, D.P., O`Brien, B., O’Callaghan, E.J., Sullivan, K.O., Meaney, W.J.,Temporal Trends in Bulk Tank Somatic Cell Count and Total Bacterial Count in Irish Dairy Herds During the Past Decade, J Dairy Sci., 89, pp. 4083-4093 (2006).

[10] Schukken, Y. H.; Weersink, A.; Leslie, K. E.; Martin, S. W., Dynamics and Regulation of Bulk Milk Somatic Cell Counts, Can JVet Res, 57, 131-135 (1993).

[11] Norman, H. D.; Walton, L. M., Somatic cell counts of milk from Dairy Herd Improvement herds during 2013, CDCB Research Report, SCC15 (2014). 
[12] SPSS. 1998. Statistical Package for the Social Science. SPSS Inc., Chicago, IL.

[13] PREVALENCE of Contagious Mastitis Pathogens on U.S. Dairy Operations. Washington:

[14] Neave F. K., Dodd F. H., Kingwill R. G., Westgarth D. R., Control of mastitis in the dairy herd by hygiene and management, JDairy Sci, 52, pp. 696-707 (1969).
[15] Oliveira, E. F.; Brito, M. A. V. P.; Lange, C. C.; Hylario, S. M.; Bruno, A.F.; Silva, M. R.; Souza, G. N.,Estimate of Staphylococcus aureus and Streptococcus agalactiae prevalence among dairy herds from Minas Gerais Holstein Dairy Association, Brazil, 2011/2012. In: 52 National Mastitis Council Annual Meeting, San Diego (52 National Mastitis Council Annual Meeting Proceedings), pp. 209-210 (2013).

Citation: Liz Gonçalves Rodrigues, Maria Helena Cosendey de Aquino, Márcio Roberto Silva, Letícia Caldas Mendonça, Juliana França Monteiro de Mendonça, Guilherme Nunes de Souza, Comparison of a Time Series Analysis of Bulk Tank Somatic Cell Counts of Dairy Herds Located in Brazil and the United States. ARC Journal of Animal and Veterinary Sciences. 2017; 3(4):34-40. doi: dx.doi.org/ 10.20431/2455-2518.0304005.

Copyright: (C) 2017 Authors. This is an open-access article distributed under the terms of the Creative Commons Attribution License, which permits unrestricted use, distribution, and reproduction in any medium, provided the original author and source are credited. 